\title{
Kontribusi Perilaku Game Online Terhadap Motivasi Belajar siswa SMA
}

\author{
Denis Wengku Tri Atmojo \\ Fakultas Psikologi, Universitas Muhammadiyah Malang \\ e-mail: denizwengku@gmail.com
}

\begin{abstract}
The online gaming behaviour referred to in this study is an individual response or reaction to the stimulation of online games or games connected via the Internet network. One factor that can influence the motivation to learn is the external factor or environmental factors that are parents, with the social support of parents then students should students have a high motivation to learn. The purpose of this research is to know the contributions of the behavior of online gaming to the learning motivation of high school students. This research is quantitative research with correlational design. The subject of this research was Shalahuddin high school student 94 students. The techniques used in sampling are total sampling techniques or saturated samples. The measuring instrument used in this study uses two scales of the scale of online gaming behaviour and learning motivation. The results showed that there was a link between the behavior of online gaming with the motivation of learning students $(P=0.000>0.05, r=-0.432)$ that is, there is a negative relationship between online gaming behaviour and the students ' learning motivation so that more students Spend time playing games online then the motivation of learning is getting lower.
\end{abstract}

KEYWORDS Online gaming behaviour, learning motivation, High School.

CITATION Atmojo, D. W. T. (2019). Kontribusi erilaku game onliine terhadap motivasi belajar siswa SMA. Cognicia, 7(4), 527-538

Bisnis warnet di Indonesia semenjak beberapa tahun terakhir terlihat sangat pesat. Di beberapa warnet umumnya terlihat dipenuhi oleh kalangan pelajar yang selalu datang untuk menghabiskan waktunya bermain game online dan terkadang mereka rela untuk tidak masuk sekolah (bolos) hanya demi bermain game online. Banyak fakta yang kita jumpai, dengan pergi survey ke warnet-warnet maka tidak jarang kita menemukan kalangan remaja bahkan anak-anak yang sedang main game online. Dari berbagai warnet yang bisa ditemui di sekitar Jakarta, hampir mayoritas ada pukul 07.00 sampai pukul 12.00 depenuhi oleh anak-anak dengan pakaian seragam sekolah yang sedang bermain game online.

Game online sendiri biasa dimainkan diusia remaja. Masa remaja yaitu suatu periode penting dari rentang kehidupan, periode transisional, masa perubahan, masa usia 
bermasalah, masa dimana individu mencari identitas diri, usia menyeramkan (dreaded), masa unrealism, serta ambang menuju kedewasaan (Krori, 2011). Soleman (2012) dampak negatif bermain game ada 3 yaitu secara sosial: hubungan dengan teman, keluarga menjadi renggang, menjadi terisolir dari teman-teman dan lingkungan karena pergaulan sebatas hanya di game online, keterampilan berkurang, perilaku menjadi kasar dan agresif. Secara psikis: sulit menjadi berkonsentrasi, kurang peduli terhadap hal sekelilingnya, melakukan apapun demi bisa bermain game seperti berbohong, mencuri, uang, sulit mengekspresikan diri ketika berada dilingkungan sekitar. Secara fisik: dalam penggunaan lama dapat merusak saraf mata dan otak, sering begadang dapat merusak beberapa organ tubuh seperti ginjal, lambung, kurangnya makan, minum, dan berolahraga, mudah lelah, dan yang paling parah dapat menyebabkan kematian. Pada tahun 1974, WHO memberikan definisi konseptual tentang remaja, meliputi kriteria biologis, psikologis, dan sosial ekonomi. Menurut WHO (Sarwono, 2011), remaja adalah suatu masa di mana: 1. Individu berkembang dari saat pertama kali ia menunjukkan tanda-tanda seksual sekundernya sampai saat ia mencapai kematangan seksual (kriteria biologis). 2. Individu mengalami perkembangan psikologis dan pola identifikasi dari kanak-kanak menjadi dewasa (kriteria sosial-psikologis). 3. Terjadi peralihan dari ketergantungan sosialekonomi yang penuh kepada keadaan yang relatif lebih mandiri (kriteria sosial-ekonomi). Hurlock (1990) membagi masa remaja menjadi dua, yaitu masa remaja awal (11-17 tahun) dan remaja akhir (17-18 tahun). Pada masa remaja akhir, individu sudah mencapai transisi perkembangan yang lebih mendekati masa dewasa.

Salah satu hal yang membuat siswa malas belajar adalah game online. Game online adalah suatu bentuk permainan yang dihubungkan melalui jaringan internet. Game online tidak terbatas pada perangkat yang digunakan, game online bisa dimainkan di komputer, laptop, dan perangkat lainnya, asal gadget tersebut terhubung dengan jaringan internet (Aji, 2012). Game (Permainan) merupakan model dari suatu kehidupan nyata yang permasalahannya disajikan secara sederhana. Fungsi dasar dari permainan adalah meningkatkan intensitas pengalaman manusia, dengan sifat yang relatif aman tetapi dapat menciptakan ketegangan dan kesenangan.

Motivasi belajar merupakan daya penggerak yang ada dan timbul dalam dari siswa untuk belajar atau meningkatkan pengetahuan (Yamin, 2007; Hamalik, 2008; Sardiman, 2012). Menurut Terry (2003), motivasi dapat diartikan sebagai suatu usaha agar seseorang dapat menyelesaikan pekerjaannya dengan semangat karena ada tujuan yang ingin dicapai. Jika kebutuhan untuk mencapai sebuah tujuan dirasa sangat mendesak maka pada saat itu juga motivasi akan menjadi aktif (Sardiman, 2010). Azwar (2000) berpendapat bahwa motivasi adalah rangsangan atau dorongan atau pembangkit tenaga yang dimiliki seseorang ataupun sekelompok masyarakat yang ingin melakukan sesuatu dan bekerjasama secara optimal dalam melaksanakan sesuatu yang direncanakan untuk mencapai tujuan yang ditetapkan. 
Menurut Uno (2008) motivasi memiliki peran penting dalam belajar yaitu (a) menentukan hal-hal yang dapat dijadikan penguat belajar, (b) memperjelas tujuan belajar yang hendak dicapai, (c) menentukan ragam kendali terhadap rangsangan belajar, dan (d) menentukan ketekunan belajar. Motivasi merupakan faktor yang mempengaruhi keberhasilan dan salah satu teknik dalam mengembangkan kemampuan dan kemauan belajar siswa disekolah (Suprihatin, 2015; Saptono, 2016). Dalam beberapa tahun terakhir relevansi tentang motivasi belajar siswa mengalami peningkatan kesadaran demi tercapainya hasil pendidikan yang positif (Taylor, at al, 2014). Maka dari itu temuan baru untuk meningkatkan motivasi belajar siswa perlu dilakukan.

Adanya dua jenis motivasi yang saling berhubungan, yakni motivasi instrinsik adalah keinginan dan mencoba untuk mengalahkan rintangan demi mengerjar tujuan itu sendiri. Contoh : siswa yang mencoba belajar sangat giat demi mencapai pretasi yag memuaskan. Sedangkan motivasi ekstrinsik yaitu mencoba sesuatu demi mencapai tujuan lainnya. Hal ini didorong oleh insentif luar semisal imbalan dan hukuman. Hal ini juga didasarkan pada aspek yang tidak berhubungan dengan aktivitas dalam diri tetapi lebih didasarkan pada faktor dari luar. Misalkan, siswa yang belajar dengan giat ingin mencapai nilai yang tinggi (Santrock, 2011).

Purwanto (2008) menyebutkan terdapat 2 faktor yang mempengaruhi motivasi belajar yaitu faktor instrinsik terdiri dari minat, cita - cita, dan kondisi siswa, sedangkan faktor ekstrinsik terdiri dari penghargaan dan pujian, peran orangtua, peran pengajar, dan kondisi lingkungan. Penelitian Gentile (2009) melakukan research lab di Iowa State University, mengemukakan yaitu lamanya bermain video game dapat memunculkan masalah pada fokus dan terlalu aktif lebih tinggi, anak menjadi ketagihan, fobia, gelisah, depresi sosial menjadikan nilai turun, terlebih banyak kejadian yang terlihat yakni bergantungnya pada game online menjadikan waktu belajar berkurang dan jauh dari teman sebaya dikarenakan hanya bermain game online saja, tidak melihat keadaan sekitar, dan akan menyebakan kemampuan bersosialiasi menjadi berkurang.

Menurut Skinner (1983), perilaku adalah respons atau reaksi seseorang terhadap stimulus atau rangsagan dari luar. Dan ada juga teori Skinner yang disebut S-O-R (Stimulus-Organisme-Repons) yaitu mengatakan perilaku dibagi menjadi 2: yang pertama perilaku tertutup (covert behaviour), yaitu perilaku yang tidak dapat diamati oleh orang lain. Yang kedua perilaku terbuka (overt behaviour), yaitu perilaku yang dapat diamati oleh orang lain berupa tindakan atau praktek.

Adapun dampak positif dan negatif dalam bermain game. Dampak positifnya yaitu menambah berkonsentrasi, meningkatkan ketajaman mata, meningkatkan kemampuan berbahasa Inggris, meningkatkan kinerja otak dan membantu otak dalam menyerap cerita, dan menghilangkan stress. Contohnya adalah game Tetris yang dianggap sebagai game online untuk membangun pengembangan IQ, karena game ini membutuhkan semangat, kecepatan, dan daya logika yang tinggi. Dampak negatifnya yaitu menimbulkan efek ketagihan, membuat orang terisolir dari kehidupan disekitarnya, 
membuat orang menjadi malas, mengganggu kesehatan, menimbulkan masalah psikologis apabila terlalu dipikirkan, mengganggu kehidupan di dunia nyata, dan pemborosan apabila kecanduan game online. Contohnya adalah game Counter Strike yang dianggap game online untuk membangun kecepatan, kerjasama tim, koordinasi mata dan tangan, dll. Tetapi di sisi lain itu dapat menjadikan orang tersebut menjadi kurang tidur, kurang bersosialisasi, perilaku agresif, dan suka berbohong (Siti, 2016).

Menurut penelitian Adhim (2004) dalam artikelnya, mengemukakan yaitu anak yang senang bermain game adalah anak yang mempunyai kemauan. Para anak tidak menyukai stimulus yang monoton, tidak menantang, dan lemah. Menyebabkan proses belajar tidak menarik dan menjadikan anak seperti penjara bagi jiwanya. Tubuhnya ada di kelas tetapi rasa penasaran, kenginannya pada game, pikiran masih tidak fokus. Semisal belajar tetapi bayangan yang ada dipikirannya masih pada game. Terkadang siswa bisa menjadi malas belajar atau mebolos kelas demi bermain game. Dari peneliti sebelumnya mengemukakan anak yang gemar bermain game mempunyai orientasi, pemikiran yang tinggi, bermotivasi. Akan tetapi game berkembangnya dan semakim canggih pada abad 21, muncul pertanyaan apakah game dapat mempengaruhi orientasi prestasi pada seseorang.

Sebelumnya terjadi di Sekolah Dasar Negeri 015 Kelurahan Sidomulyo Kecamatan Samarinda, dikarenakan para siswa di tempat tersebut mengalami perubahan perilaku motivasi belajar menurun dapat diamati dari observasi awal yang dibuat, melihat siswa saat belajar di kelas lebih asyik sendiri, mengobrol bersama teman sebangkunya, bengog, dan tidak konsen pada pelajaran yang menjadikan nilai akademiknya turun atau tidak memenuhi kriteria, dikarenakan para siswa lebih menyukai dan sering memainkan game, dan di sekitar sekolah banyak warnet yang memberikan fasilitas permainan game online, itulah pengamatan peneliti saat melakukan penelitian awal di sekolah tersebut. (Angela, 2013)

Menurut Anggraini (2014) pengguna Internet berdasarkan usia 12 sampai 21 tahun yang berjumlah 98 responden. Lama menggunakan game online dari 98 responden yaitu memiliki 22 responden (22,4 \%) menyatakan bahwa lamanya mereka bermain game online adalah satu tahun. Terdapat 50 responden $(51,0 \%)$ menyatakan lamanya mereka bermain game online adalah dua tahun. Terdapat 16 responden $(16,3 \%)$ menyatakan bahwa lamanya mereka bermain game online adalah Tiga Tahun. Kemudian terdapat 10 responden (10,2\%) bahwa lamanya mereka bermain game online adalah empat tahun.

Di salah satu SMA di kota Malang dari asesmen wawancara yang telah dilakukan peneliti pada tanggal 13 Oktober 2016, telah dilakukan interviu kepada kepala sekolah bahwa siswa memiliki motivasi belajar yang rendah dan beberapa nilai akademik yang kurang. Peneliti juga meinterviu siswa, hampir siswa tidak memiliki semangat atau tidak memiliki kemauan dalam belajar disebabkan beberapa faktor yaitu, bosan, mengantuk, capek, serta kurang perhatian dari orangtua. Motivasi rendah bisa terlihat dari 
pengamatan yang telah dilakukan saat pembelajaran oleh peneliti yaitu siswa bermain hp di kelas, berbicara dengan teman sebangku sehingga tidak memperhatikan guru saat mengajar, tidur saat pelajaran berlangsung, di pagi hari sebelum bel kelas dimulai banyak siswa mengerjakan PR, dan pada akhirnya terlambat mengumpulkan tugas rumah. Dari interviu yang telah dilakukan lebih lanjut kepada kepala sekolah, beliau mengatakan bahwa banyaknya siswa yang berasal dari keluarga ekonomi menengah. Dikarenakan orangtua siswa bekerja di luar kota dan rata-rata siswa berasal dari luar kota sehingga siswa di serahkan kepada keluarga. Sehingga orangtua yang tidak mempunyai waktu luang bersama anaknya menjadikan perhatian anak teralihkan ke gadget.

Berdasarkan uraian diatas, maka rumusan masalah penelitian ini adalah "Berapa besar kontribusi dari perilaku game online terhadap motivasi belajar siswa SMA?". Sedangkan penelitian ini bertujuan untuk mengetahui kontribusi dari perilaku game online terhadap motivasi belajar siswa SMA. Dan manfaat dari penelitian ini ada 2 yaitu secara teoritis, hasil penelitian ini diharapkan dapat memberikan sumbangan pemikiran dan perbendarahaan kepustakaan kepada peneliti-peneliti berikutnya, terutama bagi peneliti yang berasal dari kajian ilmu yang terkait dengan penelitian ini. Dan secara praktis, hasil penelitian ini diharapkan dapat memberikan dampak positif dari game online terhadap motivasi belajar siswa untuk meningkatkan prestasi belajarnya. Juga orang tua serta pihak sekolah mampu membimbing, mengimbangi, mendukung serta mengarahkan teknologi kepada perilaku anak yang positif.

\section{METODE}

Penelitian ini menggunakan pendekatan kuantitatif. Pendekatan kuantitatif merupakan penelitian yang menekankan analisanya pada data-data numerikal (angka) yang diolah dengan statistik. Pendekatan kuantitatif yang digunakan yaitu penelitian korelasional. Desain penelitian korelasional yaitu meneliti sejauh mana perbedaan dalam satu karakteristik atau variabel yang dihubungkan dan langsung mencari keberadaan hubungan dan tingkat hubungan variabel yang direfleksikan dalam koefisien korelasi (Sugiyono, 2007).

Subjek dalam peneltian ini sebanyak 94 siswa dari kelas X-XII SMA Salahuddin Malang. Teknik pengambilan sampel ini menggunakan nonprobability sampling, yaitu teknik pengambilan sampel yang tidak memberi peluang/kesempatan sama bagi setiap unsur atau anggota populasi untuk dipilih menjadi sampel dan jenis pengambilan menggunakan total sampling atau sampel jenuh yaitu teknik penentuan sampel bila semua anggota populasi digunakan sebagai sampel. Hal ini sering dilakukan bila jumlah populasi relatif kecil, kurang dari 30 orang, atau penelitian yang ingin membuat generalisasi dengan kesalahan yang sangat kecil. Jumlah sampel pada penelitian ini mengacu pada tabel Isaac dan Michael (Sugiyono, 2013) dengan taraf kesalahan 5\% dari keseluruhan jumlah populasi, maka jumlah subjek dalam penelitian ini adalah 75 siswa sebagai responden. Istilah lain sampel jenuh adalah sensus, dimana semua anggota 
populasi dijadikan sampel (Sugiyono, 2014). Karakteristik : 1) siswa SMA yang bermain game online, 2) bermain game online 4-6 jam.

Pada penelitian ini perilaku game online merupakan variabel bebas $(X)$ dan motivasi belajar merupakan variabel terikat (Y). Perilaku Game Online yang dimaksud dalam penelitian ini yaitu suatu aktivitas yang mengalami perubahan dalam individu, dimana perilaku dibagi menjadi 2 yaitu refleksi dan non-refleksi. Perilaku refleksi yaitu perilaku yang terjadi pada individu dimana secara otomatis karena rangsangan dari luar. Sedangkan non-refleksi yaitu perilaku yang tidak langsung terjadi pada individu melainkan melalui kognitif, afektif, atau psikomotor. Dan pada dasarnya perilaku mempunyai tujuan supaya menghindari ancaman yang merusak keberadaan individu, sehingga individu dapat berperilaku dan berkembang normal (Pradita, 2014; Desmita, 2009; Syarif, 2015; Sary, 2015).

Perilaku game online yang dimaksud adalah suatu aktivitas yang mengalami perubahan dalam individu, dimana perilaku secara otomatis karena rangsangan luar, dan melalui kognitif (pikiran), afektif (perasaan), dan psikomotor (kemampuan bergerak). Perilaku game online menggunakan skala yang dibuat Dewandari (2013). Dari teori Cowie (1994) intensitas bermain game online mencakup dua aspek yaitu, kuantitas yang menyatakan besarnya waktu yang dipergunakan untuk bermain dan aktivitas yang merupakan kegiatan yang mengarah pada seringnya seorang individu bermain game. Berdasarkan hasil validitas alat ukur dengan menggunakan metode try out yang diberikan kepada 50 siswa SMK Shalahuddin Malang, maka didapatkan hasil sebanyak 21 item valid dan 9 item dinyatakan gugur (tidak valid) dengan indeks sebesar $0.276-0.711$ dan reliabilitas sebesar 0.892 .

Dalam hal ini deifnisi motivasi adalah proses usaha yang dilakukan melalui dalam dan luar diri siswa demi mencapai hasil belajar yang memuaskan. Motivasi belajar diukur menggunakan skala yang dirancang oleh Khasanah (2013). Berlandaskan teori Sardiman (2016) dan Uno (2009) yang terdiri dari indikator kesungguhan dalam menghadapi tugas, tidak mudah menyerah menghadapi kesulitan, senang bekerja mandiri, percaya dengan yang dilakukan, senang mencari dan memecahkan soal-soal, adanya minat dan keinginan berhasil, dorongan dan kebutuhan dalam belajar, kegiatan yang menarik dalam belajar dan lingkungan belajar yang mendukung. Setelah dilakukan try out menghasilkan 31 item valid dan 19 item dinyatakan gugur (tidak valid) dengan indeks validitas sebesar 0.272 0.723 dan nilai reliabilitas yaitu 0.896 .

Tabel 1. Nilai psikometri alat ukur 


\begin{tabular}{lcccc}
\hline \multicolumn{1}{c}{ Alat Ukur } & $\begin{array}{c}\text { Jumlah Item } \\
\text { diujikan }\end{array}$ & $\begin{array}{c}\text { Jumlah Item } \\
\text { Valid }\end{array}$ & Indeks Validitas & $\begin{array}{c}\text { Nilai } \\
\text { Reliabilitas } \\
\text { (Crobach's } \\
\text { Alpha })\end{array}$ \\
\hline Skala Game Online & 30 & 20 & $0.213-0.711$ & 0.917 \\
\hline $\begin{array}{l}\text { Skala Motivasi } \\
\text { Belajar }\end{array}$ & 50 & 39 & $0.180-0.512$ & 0.842 \\
\hline
\end{tabular}

Prosedur penelitian dalam riset ini memiliki tiga tahap, yaitu :

Fase awal peneliti menmpersiapkan kuesioner perilaku game online dan motivasi belajar. Skala perilaku game online adalah skala dirancang Cowie (1994) sedangkan skala motivasi belajar yaitu hasil dari Khassanah (2013) yang memakai tryout terpakai.

Fase berikutnya membagikan angket atau kuesioner perilaku game online dan motivasi belajar di SMA Shalahuddin Malang. Kemudian peneliti mendatangi sekolah SMA Shalahuddin Malang dan menemui langsung bapak kepala sekolah untuk memberikan izin membagikan kuesioner, pembagian kuesioner dilakukan selama 2 hari yaitu Selasa dan Rabu, 21-22 Mei 2019. Penyebaran didampingi oleh bapak kepala sekolah, dan dibantu dengan rekan dalam penyebaran. Kemudian peneliti menjelaskan terlebih dahulu cara mengisi kuesioner, memberikan beberapa waktu untuk mengisi kuesioner, menunggu pengisian sampai selesai dan angket atau kuesioner dikumpulkan.

Fase terakhir, melakukan penilaian atau skoring terhadap kuesioner yang sudah diisi oleh siswa, setelah dilakukannya penilaian, angket tersebut langsung menginput ke progtam perhitungan Statistical Package For Social Sciense (SPSS) versi 21. Kemudian melakukan uji normalitas dengan bertujuan untuk melihat data yang diperoleh normal atau tidak. Setelah melakukan uji normalitas dan hasil yang didapat yaitu normal, yang kemudian dilakukannya analisa utama yaitu analisa korelasi person atau korelasi product moment.

HASIL

Penelitian ini dilakukan di SMA Shalahuddin Malang dengan subjek sebanyak 75 siswa yang disebarkan ke kelas 10, 11 dan 12. Adapun hasil penlitian sebagai berikut:

Tabel 2. Deskriptif Subjek

\begin{tabular}{lcc}
\hline \multicolumn{1}{c}{ Kategori } & Frekuensi & Presentase \\
\hline Jenis Kelamin & & \\
Laki-laki & 49 & $65,3 \%$ \\
Perempuan & 26 & $34,7 \%$ \\
\hline
\end{tabular}

Kelas 
10

11

12
30

30

15
$40 \%$

$40 \%$

$20 \%$

Dapat dilihat bahwa dari 75 siswa terdapat 49 responden sekitar $(65,3 \%)$ siswa berjenis kelamin laki-laki, dan 26 responden sebesar $(34,7)$ siswa perempuan. Dan menurut pembagian kelas terdapat 10 sekitar (40\%), kelas 11 sebanyak (40\%), dan kelas 12 sebesar (20\%).

Tabel 3. Klasifikasi Game Online dan Motivasi Belajar

\begin{tabular}{lcc}
\hline \multicolumn{1}{c}{ Kategori } & Frekuensi & Presentase \\
\hline Game Online & & \\
Tinggi & 16 & \\
Sedang & 47 & $21,3 \%$ \\
Rendah & 12 & $62,7 \%$ \\
& & $16 \%$ \\
Motivasi Belajar & & \\
Tinggi & 11 & $14,7 \%$ \\
Sedang & 52 & $69,3 \%$ \\
Rendah & 12 & $16 \%$ \\
\hline
\end{tabular}

Hasil dari skor skala game online diperoleh hasil 16 (21,3\%) subjek bermain game online yang tinggi, 47 (62,7\%) subjek bermian game online sedang, dan 12 (16\%) subjek bermain game online yang rendah. Kemudian, hasil skor kuesioner motivasi belajar didapatkan 11 (14,7\%) responden mempunyai motivasi belajar tinggi, 52 (69,3\%) responden terdapat motivasi belajar sedang, dan 12 (16\%) responden mempunyai motivasi belajar yang rendah.

Tabel 4. Uji Normalitas

\section{Game Online} 0,801
Motivasi Belajar

0,973

Dari uji normalitas non parametrik yang sudah dilakukan memakai koefisien product moment menyatakan yaitu angka yang diperoleh dari skala game online yaitu 0,801 yakni data normal, selain itu angka yang diperoleh skala motivasi belajar yaitu 0,973 yakni data normal. Dikatakan normal sebab hasil uji lebih tinggi dari 0,05 atau diatas 0,05.

Tabel 5. Uji Korelasi 


\begin{tabular}{llll}
\hline Koefisien & Koefisien & Sig./p & Keterangan \\
Korelasion $(r)$ & Determinasi $\left(\mathrm{r}^{2}\right)$ & &
\end{tabular}

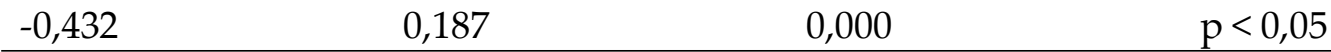

Dari analisa korelasi pearson atau korelasi product moment, dapat dilihat yaitu nilai korelasi ( $\mathrm{r}$ ) sebesar -0,432 artinya ada hubungan negatif antara game online dengan motivasi belajar siswa. Di samping itu, hasil analisa data juga membuktikan nilai signifikan $(\mathrm{p})=0.000<0.05$ yakni kedua variabel tersebut terdapat hubungan yang signifikan, maksudnya perilaku game online berhubungan dengan motivasi belajar siswa sehingga semakin banyak siswa menghabiskan waktu bermain game online maka motivasi belajar siswa semakin rendah dan sebaliknya.

\section{DISKUSI}

Penelitian ini menunjukkan yaitu saling berkaitan antara perilaku game online dengan motivasi belajar siswa. Hal ini dapat dilihat dari hasil penelitian sebelumnya, dimana hasil tersebut memberikan nilai korelasi (r) -0,432 yang berati ada hubungan negatif antara perilaku game online terhadap motivasi belajar siswa.

Penelitian ini selaras dengan penelitian yang telah dilakukan oleh Saptarini (2013) ditemukan hasil bahwa ada hubungan yang signifikan dengan arah negatif antara intensitas bermain game online dengan motivasi belajar siswa, dan adanya hubungan signifikan antara intenistas bermain game online terhadap motivasi belajar di sekolah.

Salah satu hal yang membuat motivasi belajar siswa akan pentingnya belajar yaitu dengan memberikan reinforcement. Reinforcement atau penguatan yaitu motivasi yang bertujuan agar terjadinya pengulangan terhadap tingkah laku yang diberi penguatan (Skinner, 1953). Pengaplikasian reinforcement oleh guru akan membuat siswa merasa dihargai setiap usaha yang telah dilakukannya. Siswa akan mengetahui respon dan perilaku mana yang baik dan bersifat positif, sehingga secara sadar siswa akan mengulangi kembali melakukan respon dan perilaku tersebut. Bentuk penguatan yang diberikan oleh guru terhadap tingkah laku positif yang ditunjukkan oleh siswa dapat berupa pemberian reward dalam bentuk benda (hadiah), verbal (seperti pujian), dan juga dalam bentuk tingkah laku yang hangat, permisif (bebas), dan penuh penerimaan.

Schunk (2012) motivasi ekstrinsik adalah motivasi melibatkan diri dalam sebuah aktifitas sebagai suatu cara mencapai sebuah tujuan. Individu yang termotivasi secara ekstrinsik mengerjakan tugas karena mereka meyakini bahwa partisipasi tersebut akan menyebabkan berbagai konsekuensi yang diinginkan, seperti mendapatkan hadiah, menerima pujian dari guru, atau terhindar dari hukuman. Jadi motivasi atau dorongan yang timbul dari luar diri seseorang tersebut, bisa dikatakan bahwa motivasi ekstrinstik diperlukan bila motivasi instrinstik itu tidak ada dalam diri seseorang tersebut. Jadi motivasi ekstrinstik ini sangat di perlukan jika motivasi dalam diri seseorang itu sudah tidak ada lagi. Faktor eksternal selain orangtua yang dapat mempengaruhi motivasi 
belajar, yaitu faktor lain yang berasal dari lingkungan sekitar seperti guru, konselor, teman sebaya, dan tetangga. Contoh : pada mulanya siswa ini tidak ada hasrat untuk belajar, tetapi karena ada sesuatu yang dicari muncullah minatnya dalam belajar.

Perilaku game online adalah suatu aktivitas yang mengalami perubahan dalam individu, dimana perilaku dibagi menjadi 2 yaitu refleksi dan non-refleksi. Perilaku refleksi yaitu perilaku yang terjadi pada individu dimana secara otomatis karena rangsangan dari luar. Sedangkan non-refleksi yaitu perilaku yang tidak langsung terjadi pada individu melainkan melalui kognitif, afektif, atau psikomotor. Dan pada dasarnya perilaku mempunyai tujuan supaya menghindari ancaman yang merusak keberadaan individu, sehingga individu dapat berperilaku dan berkembang normal (Desmita, 2009; Pradita, 2014; Sary, 2015; Syarif, 2015).

Menurut penelitian Novita (2018) menunjukkan bahwa hubungan bersifat negatif atau berlawanan arah antara self control dengan intensitas bermain game online yang artinya semakin rendah perolehan skor self control maka semakin tinggi intensitas bermain game online. Beberapa faktor yang dapat mempengaruhi siswa bermain game online, yaitu intrinsik dan ekstrinsik. Intrinsik : (a) ingin mendapatkan nilai tinggi dalam bermain, (b) rasa bosan ketika dirumah atau disekolah, (c) lebih mementingkan bermain game online dari pada lainnya, (d) kurangnya pengendalian diri saat bermain. Ekstrinsik : (a) bermain karena ajakan teman sebaya, (b) kurang mmiliki hubungan sosial yang baik, (c) tertekan oleh orang tua yang mempunyai harapan tinggi pada siswa.

Dapat disimpulkan bahwa hubungan perilaku game online terhadap motivasi belajar siswa memiliki hubungan bersifat negatif yang artinya semakin banyak siswa menghabiskan waktu bermain game online maka motivasi belajar akan rendah dan sebaliknya. Hal ini disebabkan banyak faktor yang dapat membuat motivasi belajar menjadi turun karena game online, baik itu secara internal maupun eksternal.

\section{SIMPULAN DAN IMPLIKASI}

Berdasarkan hasil penelitian dapat diasumsikan dalam penelitian ini yakni ada hubungan negatif antara perilaku game online terhadap motivasi belajar siswa diterima. Dari penelitian menunjukkan bahwa tidak ada hubungan yang signifikan antara perilaku game online dan motivasi belajar. Hal ini berarti perilaku bermain game online berhubungan dengan motivasi belajar siswa sehingga semakin banyak siswa menghabiskan waktu bermain game online maka motivasi belajar rendah dan sebaliknya.

Bagi orangtua, walaupun ada perilaku game online terhadap motivasi belajar siswa, orangtua harus tetap mengawasi, dan membimbing anaknya saat bermain game online supaya motivasi anak tidak menurun, sehingga orangtua bisa menjaga motivasi anak tetap positif saat belajar, baik akademik maupun non-akademik. Bagi siswa agar dapat merubah perilaku bermain game online ke arah yang lebih positif. Bagi siswa yang mengalami masalah mengenai perilaku bermain game online dan motivasi belajar 
menurun dapat meminta bantuan kepada guru BK. Hal tersebut bukanlah hal yang sulit apabila yakin dan tindak mengunci pikiran bahwa tidak akan bisa merubah perilaku ke arah yang lebih positif. Bagi pihak sekolah penelitian ini bisa dijadikan rujukan dalam proses pembelajaran untuk memperhatikan hubungan game online dengan motivasi belajar, walaupun disekolah sudah disediakan fasilitas yang memadai. Selain itu, untuk peneliti selanjutnya supaya dapat meneliti dengan mencari faktor-faktor lain yang mempengaruhi motivasi belajar selain perilaku game online, karena dalam penelitian ini belum dibahas lebih lanjut.

\section{REFERENSI}

Adhim, M. F. (2004). Membuat anak gila membaca. Bandung: Mizan Pustaka.

Aji, C.Z. (2012). Berburu rupiah lewat game online. PT. Bounabooks.

Angela. (2013). Pengaruh game online terhadap motivasi belajar siswa SDN 015 Kelurahan Sidomulyo Kecamatan Samarinda Ilir. E-Jounal Ilmu Komunikasi, 1(2) : 532-544.

Anggraini, Y. (2014). Dampak penggunaan game online terhadap perilaku remaja (Studi deskriptif kuantitatif pada remaja di Kelurahan Asam Kumbang Medan). Universitas Sumatera Utara.

Azwar, S. (2000). Sikap manusia teori dan pengukurannya. Edisi ke 2. Cetakan IV. Yogyakarta (ID). Pustaka Pelajar.

Chaplin, J. P. (2001). Kamus lengkap psikologi. Jakarta: Raja Grafindo Persada.

Cowie. (1994). Advanced Learner's Dicitionary. (4th ED). Britain: Oxford University Press.

Desmita. (2009). Psikologi perkembangan peserta didik. Batusangkar: PT Remaja Rosdakarya.

Dewandari, S. (2013). Hubungan antara intensitas bermain game online dengan motivasi belajar siswa kelas X SMK Negeri 1 Sarupan Kabupaten Wonosobo. Skripsi, Fakultas keguruan dan ilmu pendidikan, Universitas kristen satya wacana.

Febrian, J. (2007). Kamus komputer \& teknologi informasi. Bandung : PT. Informatika.

Gentile, D. A., Anderson, C. A., Yukawa, S., Ihori, N., Saleem, M., Ming, L. K. . . . Sakamoto, A (2009). The Effects of Prosocial Video Games on Prosocial Behaviors: International Evidence From Correlational, Longitudinal, and Experimental Studies. Personality and Social Psychology Bulletin, 35, 752-763.

Hamalik, O. (2008). Kurikulum \& pembelajaran. Jakarta: Sinar Grafika.

Hurlock, E. B. (1990). Developmental Psychology: A Lifespan Approach. (terjemahan oleh Istiwidayanti). Jakarta: Erlangga Gunarsa.

Khasanah, A. Z. (2013). Meningkatkan motivasi belajar siswa underachiever melalui layanan bimbingan kelompok pada siswa SD Negeri Pekunden Semarang. Skripsi. Semarang: Universitas Negeri Semarang.

Krori, Smita Deb. (2011). Developmental psychology, dalam hemopathic journal :: Volume 4, issue: 3, Jan, 2011. Tersedia: http://www.homerizon.com/homeoathicarticles/psychology/developmental-psychology. (14 Februari 2012)

Notoatmodjo, S. (2010). Ilmu perilaku kesehatan. Jakarta: Rineka Cipta.

Novita, F. R. P., (2018). Hubungan antara self control dengan intensitas bermain game online pada anak usia sekolah. Skripsi, Fakultas Psikologi, Universitas Muhammadiyah Malang.

Pradita, D. (2014). Analisis perilaku belajar dan gaya belajar anak berbakat kelas 5 Di SDN Kauman 1 kota Malang. Disertasi tidak diterbitkan. Malang: FKIP UMM. 


\section{ONLINE GAMING BEHAVIOUR, LEARNING MOTIVATION, HIGH SCHOOL.}

Purwanto, H. (1998). Pengantar perilaku manusia. Jakarta: Buku Kedokteran EGC.

Purwanto. (2008). Unsur motivasi. Jakarta : Balai Pustaka.

Purwanto, M. Ngalim. (2010). Psikologi pendidikan. Bandung: PT . Remaja Rosdakarya.

Santrock, J. W. (2011). Life-Span Development (13th Edition). New York: McGraw Hill

Sardiman, A. M. (2010). Interaksi dan motivasi belajar mengajar. Rajawali Pers. Jakarta.

Sardiman, A. M. (2012). Interaksi dan motivasi belajar mengajar. Jakarta: Raja Garfindo Persada.

Saptono, Y. J. (2016). Motivas dan keberhasilan belajar siswa. Jurnal pendidikan agama Kristen, 1(1), 189-212.

Sary, Y. (2015). Psikologi pendidikan. Yogyakarta: Parama Publishing.

Schunk, Dale, H. (2012). Motivasi dalam pendidikan: teori, penelitian, dan aplikasi. Jakarta: PT Indeks.

Siti, Y. N. (2016). Pengaruh game online terhadap motivasi belajar siswa (Studi Deskriptif Kuantitatif di SMAN 22 Bandung). Skripsi (S1) thesis, FKIP UNPAS.

Skinner, B. F. (1953). Science and Human Behavior. New York: MacMillan.

Skinner, B. F. (1983). A matter of consequences: Part three of an autobiography. New York. University Press.

Soleman, M. (2012). "Dampak negatif dari game online". http://smahangtua2.org/magazine/kesehatan/61-dampak-negatif-dari-game-online.html (diunduh Kamis, 4 April 2013)

Sugiyono. (2007). Metode penelitian kuantitatif, kualitatif dan RED. Penerbit Alfabeta Bandung.

Sugiyono (2014). Metode penelitian kuantitatif kualitatif dan RED. Bandung: Alfabeta.

Suprihatin, S. (2015). Upaya guru dalam meningkatkan motivasi belajar siswa. Jurnal Pendidikan Ekonomi, 3(1), 73-82.

Syarif, N. (2015). Pengaruh perilaku pengguna smartphone terhadap komunikasi interpersonal siswa SMK TI airlangga Samarinda. Jurnal Ilmu Komunikasi. (online), (http://ejournal.ilkom.fisipunmul.ac.id), diakses pada 23 Desember 2015.

Yusuf, S. (2009). Program bimbingan dan konseling di sekolah. Bandung: Rizqi Perss.

Taylor, G., Jungert, T., Mageau, G.A., Schattke, K., Dedic, H., Rosenfield, S., \& $\quad$ Koestner, $\quad$ R. (2014). A self-determination theory approach to predicting scholl achievement over time: The unique role of intrinsic motivation. Contemporery educational psychology, 39(4), 342-358.

Terry, G. R. (2003). Manajemen sumber daya manusia, Jilid 1. Jakarta: PT Indeks.

Uno, Hamzah, B. (2009). Teori motivasi dan pengukurannya. Jakarta: PT. Bumi Aksara.

Yamin, M. (2007). Kiat pembelajarkan siswa. Jakarta: Gaung Persada Press. 